John S. Nelson

\title{
JOHN LE CARRÉ AND THE POSTMODERN MYTH OF THE STATE
}

Most of our politics is a matter of talk: not material interests 1 alone, not military or other resources, not rational decisions by individuals or institutions - but talk. In politics, if not always in war, these other matters are configured in, of, by, and for talk. ${ }^{1}$ The popular genre of spy stories shows episode by episode, scene by scene, how political events, motives, opportunities, resources, and situations turn on talk. This holds not merely despite the international settings but because of them. Stories of international intrigue often turn on troubles of mutual translation and comprehension across cultures or institutions. These begin and end in codes and practices of talk.

At root, the very meaning of inter-national is between-or-acrossnations - where nations are peoples or cultures defined less by genes pools and territories than by distinctive languages and modes of speech. Thomas Hobbes said that only the institution of a sovereign, a modern state or government, could order people into a society, a nation; and the first thing that this "common power to keep them all in awe" must do to create a nation is to invent its language, giving the subjects a sense of mutual identity in community and a way to communicate constructively. The warlike chaos that Hobbes and the 
modern world have taken to remain between nations is therefore importantly a result of confusion and misunderstanding at the levels of language, talk, and translation. International relations are first and foremost phenomena of troubled talk. Put more broadly, modern politics recognize no international community in the strict political sense of sovereignty, and so international relations are defined by difficulties of communication. Time and again, spy stories insist on this characterization.

Troubles of talk and communication are importantly challenges of information. Late-modern spies act to keep their country's information secret from competitors. This protects their country's strategies and powers. Chief among those resources is the proprietary information or knowledge itself. In the modern world of Hobbesian sovereigns, reputation is power. In the late-modern world of nationalsecurity states, information is the power to produce or penetrate reputations. In the practice of spying, therefore, information is the supreme power. Gaining information through passive or active intelligence operations is surely the classic work of spies. They act covertly to penetrate the defenses of their competitors, to defend their own information, and to propagate misinformation, even disinformation. These three activities define spying and animate spy stories. All three are communicational, treating international relations as politics of talk - never exclusively, but almost always primarily.

\section{The Myth of the (National-Security) State}

I have always been opposed to violence, even when it's in a manner of speaking. $^{2}$

Len Deighton

Spy stories help to make the myth of the national-security state. As a concept, this has become intrinsically critical of the development of the modern nation-state into forms more bureaucratic and adventurous, both at home and abroad. Thus the genre sometimes treats the national-security state as a late-modern replacement for the modern sovereign. But the genre also treats the national-security state as a late-modern exaggeration of the modern state, especially of its worst 
proclivities. Then the genre faults the national-security state for extreme editions of the same maladies that beset any modern state. Along the way, spy stories find saving graces in a few of the departures or exaggerations practiced by the national-security state. Sovereignty, democracy, and bureaucracy are the watchwords of this critique.

The overall argument of the genre is that neither the modern state nor its national-security descendant can achieve genuine sovereignty or democracy. Conventionally the genre tends to applaud the first finding and fault the second. Nor, the genre suggests, is either type of state suited to the liberal-unto-libertarian ideal of the nightwatchman state. Instead the governments that dominate affairs of international relations are bureaucratic. Given the ambition and scale of governments late in the twentieth century, spy stories judge their bureaucratization to be less admirable than inevitable. But perhaps the most intriguing possibility raised of late by the genre is that the best governments possible for our times would surmount both nightwatchman and bureaucratic models to embrace templates such as the night-manager state recently evoked by John le Carré.

\section{Not Sovereignty ...}

"You have so many voices, Mr. Pine," she resumed, after too long. "I have no idea anymore who you are. . . You say one thing, and you are that person. And I am moved by that person. Then that person is called away, and somebody quite different takes his place. And you say something else. And I am moved again. So we have a changing of the guard." 3

John le Carré

In The Night Manager, the title character may be taken to personify the author's (and perhaps the genre's) sense of desirable government in the wake of the Cold War. Given le Carrés sharp eye for emerging conditions, the state as night-manager may even be taken more generally as a recommendation for postmodern times. The notion of states as selves, like that of selves as governments, is an old one in the west. Comparisons between polities and psyches go back at least as far as Plato's Republic, where the just commonwealth and the good 
soul are characterized in tandem. From Hobbes onward, the modern state and the modern self are idealized as rational sovereigns. Both are in complete ownership, possession, and control of their bodies and acts. But to read le Carré and other spy writers these days is to infer either that the days of sovereignty are numbered, that no sovereignty in any genuine sense ever really existed, for states or for selves, or that no sovereignty the strict sense was ever possible for states or selves. The postmodern view is that selves encompass several levels and many voices. The spy-novel convention is that states do the same. "The secret world, [le Carré] says, 'is also the national subconscious.' It takes you to the 'secret center' of a country. If you want to know the deepest longings and anxieties of any nation, then look at what its security and intelligence services are being asked to do." "But not even the secret center can be sovereign.

Moving away from the Cold War, the state no longer is nor should be a unified sovereign, speaking with only one voice. Like "the Night Manager" Jonathan Pine to his first great love, Sophie, states now have many voices at once. They may attain a kind of unity in commitment to their citizenry. Even that, however, is unlikely. Jonathan claims to have given his all to Sophie; but she suspects otherwise, and she is right. For Jonathan knowingly, though with great misgivings, betrays Sophie's trust. With grave reservations, he puts the cause of his country ahead of his love. Does this mean that a unified sovereign would be better than a multiplicitous regiment? That is not le Carré's meaning. His complex characters are seldom unified in classical or in modern terms. Nor are his states "sovereign" in most senses of the word. Even were unified selves and sovereigns possible for earlier times, le Carré shows how the spying and other covert actions of international intrigue make such unity impossible and undesirable for the diverse and dispersed conditions of late-untopostmodern politics.

Le Carrés work agrees in this regard with the conventions of international intrigue as a popular genre. Spy stories portray covert action as undoing any sovereignty as absolute authority or power within a specific territory. Add propaganda to covert action, and spying may be said to undo sovereignty as the monopoly on the legitimate means of violence in a society: Max Weber's test and definition of any modern state. The dynamics of international intrigue keep 
governments and cultures too permeable to retain the sovereign integrity of clear boundaries between the domestic and the foreign, the inside and outside. Spy stories trace how states and societies are immensely complex sets of institutions and individuals, many with standing also in other cultures and countries. In the case of double agents and dual citizens, both of whom figure prominently in spy stories, individuals may even have standing in other governments. Prominent as well are governmental institutions and their non-governmental equivalents that cut across boundaries between nominally sovereign states.

Whatever the intentions of their authors, recent spy stories tend to take modern sovereignty apart in virtually every way possible. They deconstruct modern states by covert actions, transnational institutions, revolutionary upheavals, resurgent tribes, global economies, cultural imperialisms, the multiple identities of postmodern individuals, and the cross-cutting loyalties of many peoples. Likewise spy stories tend to deconstruct modern selves: through torture and brainwashing, through the plasticity of spies, through dispersing the self-discovery plots of earlier eras. Yet spy stories also decenter states and selves. They feature economic, educational, and other institutions that stand mostly outside modern governments. Sometimes these serve as fronts for spying, but more often they become separate grounds for international intrigue.

Largely in place of modern sovereignty as unified decision and control, spy stories see postmodern government as overt and covert action coupled with political accountability. As le Carré says, "There's no such thing as a decision. There never was."

The mode of decision is too tidy and tyrannical to satisfy the genre's realistic interest in conditions, complications, improvisations, and the like. No decision stands by itself in spy stories; but no decision could stand otherwise by the standards of modern sovereignty, either for states or selves. Despite their penchant for clockwork plots, spy stories tend to challenge the modern concept of control, similarly crucial to the very idea of sovereignty. To conceive states or individuals as "controlling" in the strict sense of "sovereignty" would be to banish the intrigue from spy stories. So the genre undoes sovereignty as a political program for states or selves. Eschewing most attempts to characterize whole systems of politics at the level of the 
country, spy stories turn instead to the political excitement of covert action.

\section{... But Covert Action}

She shuffled listlessly through the cables and reports on her desk. She had already handed out the morning's assignments to her researchers, and now she was faced with reading her own stack of material, sifting through it for a relevant fact on any one of hundreds of subjects, files, and cases. This, if the thriller writers only knew, was ninety percent of what intelligence was all about; reading, remembering, associating, analyzing, and occasionally, discovering. It was mornings like this that made her sometimes yearn for foreign duty, where there was, at least, the stimulus of outside contact. ${ }^{5}$

Stuart Woods

Spy stories tend to glamorize covert action. Even realist novels and films in the genre can hardly help themselves. In Deep Lie, Stuart Woods cautions his readers and himself against romanticizing the professional life of the spy. But look at what is already happening by the last sentence, when his professional spy lets her thoughts turn to "foreign duty," with its "stimulus of outside contact." Just raise the possibility of covert action, of operations out in the field, and the spy thriller is off and running - to exciting events in exotic places.

Spy stories imply that covert actions epitomize and pervert latemodern politics. This holds primarily for international relations, but spy stories also show how their machinations infect putatively domestic politics. And in any event, international intrigues typically depend on the dissolution of many separations posited by modern politics between international and domestic realms. Spy stories know that covert action has become a persistent, characteristic focus of the foreign and defense policies of America and most other countries which have, on occasion, exercised a major influence on this century's overt, official politics among nations. This makes covert action a symbol for the international politics of our times.

Sooner or later, according to the genre, nearly all espionage tries to make in direct ways some of the changes that the spymasters want to effect in others. When le Carré's Alec Leamas, The Spy Who Came 
In from the Cold, becomes entrapped in manipulating a communist country to discredit one major figure and advance another, he passes fully (if unknowingly) into the realm of covert operations. Immersed in covert action, he enters completely into the contest of spy versus spy. As covert action across borders, tales of international intrigue project bureaucratized versions of reputational politics, eventually to the nth-degree. They display the national-security state as a covert manipulator of almost anything that comes its way. And thus they lay the foundation for one of the biggest indictments lodged by the genre of international intrigue against the professional practice of spying for late-modern states.

\section{Not Democracy ...}

"The ethic of our work, as I understand it, is based on a single assumption. That is, we are never going to be aggressors. . . Thus we do disagreeable things, but we are defensive. That, I think, is still fair. We do disagreeable things so that ordinary people here and elsewhere can sleep safely in their beds at night. Is that too romantic? Of course, we occasionally do very wicked things." He grinned like a schoolboy. "And in weighing up the moralities, we rather go in for dishonest comparisons; after all, you can't compare the ideals of one side with the methods of the other, can you now? ... I mean, you've got to compare method with method, and ideal with ideal. I would say that since the war, our methods - ours and those of the opposition - have become much the same. I mean you can't be less ruthless than the opposition simply because your government's policy is benevolent, can you now?" He laughed quietly to himself. "That would never do," he said. ${ }^{6}$

John le Carré

Spy stories tell time and again how the international intrigues of late-modern states go astray or succeed so as to debilitate and eventually destroy democracy. The Spy Who Came In from the Cold is typical in this regard, for the genre as well as for le Carré. It relies on intense figural resonance among its many levels of theme and detail to show how western democracies are torpedoed by their secret services. To save these democracies, the covert manipulations of spies are destroying them. In spy novels, this is evident in personal, everyday events as much as affairs of state. 
Since le Carré's classic contrasts democracy to political manipulation, we should ask who manipulates whom? Control manipulates Alec Leamas, his lover (Liz Gold), and the opposition. As the spy ready to come in from the cold, Alec is ripe for misuse. As a naïve leftist and lonely librarian, Liz is vulnerable to manipulation through Alec. But notice that the novel does not treat covert action as categorically "secret." Instead the whole spy apparatus is oriented as much or more to various public manipulations. Control is a power in "the Circus," a name that echoes Guy Debord, Jean Baudrillard, and Murray Edelman on politics as spectacle. ${ }^{7}$ The bread and circuses of the Roman Empire become the late-modern spectacle of political entertainment for the masses. Is it any longer "democratic?" Neither the novel nor the genre is confident that it ever was, but they suggest strongly that it is not now.

Circus and Control routinely manipulate "the public," allegedly for its own good. Spying is put in the service of lying to the local citizenry. Some of them, such as Liz, become targets of more grim and outrageous manipulations. Liz is an ordinary person who gets caught up in the spy game and destroyed, never having been asked to volunteer or approve any part of the plot. The pervasive deceit means that much the same happens to Alec. He is a run-of-the-mill, patriotic operative, still human and democratic enough to have compunctions about some kinds of covert activity. So he, too, must go.

The novel is too sophisticated to identify democracy with "right" and its opponents with "wrong." But it does show how spies and ordinary people need to believe in something akin to democracy and human decency. The specific substance is not as important as the act of belief, as even Control mentions at an early point in the story. Control's abstraction from human details is what enables him to view everything as relative to changing interests, shifting purposes in a bureaucratic war of seemingly unending attrition. Insofar as Control makes himself the epitome of the political, the novel might pit the personal against the political. The personal is moral, the political is not. But the ambiguous figure of Smiley together with the evident politics of Alec and Liz stand in the way of anything so simple. Is Leamas to take a personal stand, to stop spying in defiance of the larger political considerations about what is advantageous for his 
side to do? This personal stand need not be a good thing. Much of the book is compatible with reckoning Leamas's personal stand to be selfish, to meet his own needs to come in from the cold. He craves warmth in a loving, ordinary, true relationship. He needs caring in his life. So he sets aside the hard, cold things that must be done for the good of the espionage operation and, by extension, the free world of democratic nations. Yet the connivance of Control is supposed to save the democracies at the cost of a dupe or fellow traveler and possibly also a spy. The speeches by Control leave readers with more than a few reservations about this claim of the end justifying the means. They put into question the compatibility of democracy with the national-security state.

Take Control's longest declamation, a part quoted at the start of this section. It argues that the spy state is ethical precisely because it is willing to set aside the ordinary morality of personal life in order to defend the conditions needed for ordinary people in western democracies to get on with their lives, free of regimentation by the alien powers of the Communist East. By this end of this performance as carefully crafted by le Carré, we are troubled by the reasoning and the reasoner. In the abstract, Control's case for playing hardball politics and doing all sorts of dirty, nasty stuff might be persuasive. But the precise words and rhythms of Control tell us to think again. Maybe the evil of our side is merely responsive and defensive, not offensive. But why is the other side in that posture, and how are covert actions of the kinds implied going to stay consistent with democratic principles or procedures? Control no doubt would answer in a clever way, but would his words be persuasive after we know what he is using them to defend? Furthermore the cold-war logic of preemption twists the meanings of words like "responsive" and "defensive." So we know that Control is talking half-truths at best when he declares that there is only one big principle at issue: never to let an attack go unanswered.

Here the question of ethics is predicated on the hardball ideal of protecting us citizens through elite methods. Not only ordinary people, with their private codes of morality, but also spy stories are wont to contemplate objections. Democracy is supposed to benefit the common folk. When they are raw material for manipulation in the interest of an allegedly democratic state, can the ends still justify the 
means? Le Carré doubts it, and so do his colleagues and conventions in the genre.

These considerations of publicity are the flip side of secrecy, another theme of spy novels that ties closely to the topic of information. Secrecy is treated by the cold warrior as the withholding of information from a public. What is secret might well not be known by the enemy, and probably should not be. But in the world of spy versus spy, it definitely is not and should not be known by a public - even on your own side. Such secrecy is the antithesis of democratic politics which depend on visibility. ${ }^{8}$ Democratic politics are supposed to be overt and public, not covert and secret, so that citizens can know enough about what is happening to join in the making of public decisions.

Secrecy states are national-security states: antithetical to liberal, democratic, and even republican modes of government. National-security states rely on secret agencies or bureaus of government, usually in the fives and tens so that one arm will not (need to) know what the others are doing. These agencies are to do things exactly counter to the overall ethos, the atmospherics and principles, of democratic regimes. The cold-war argument is that this is the only way to protect democracies in hard and dangerous times. The need is to fight fire with fire, and the enemy's secrecy with our own. Seldom are democratic publics good at organizing themselves to face subtle threats and sustained crises. Republics might provide for crisis leadership in international relations through the office of the dictator or, more likely, a presidency modeled on the Roman institution. Yet democratic politics tend to distort such an institution by hedging it in with various electoral concerns and countervailing powers. When we "know" that the enemy will resort to all sorts of evil deeds and dirty tricks, the realistic response is to reply in kind and to anticipate, even pre-empt, this if at all possible. Yet these are the kinds of deeds that cannot be decent in democratic terms. Therefore they cannot be acknowledged publicly without officials and their agents suffering disgrace, impeachment, resignation, or the like. But in the secrecy-security state, by contrast, these official resources need not be squandered in such ways. The dirty deeds of covert action remain secret, not so much from the other side as from the public on our own.

Spy stories do not rule out the possibility that the visibility of 
democracies might need protection by the invisibility accorded cadres of secret agents who engage in covert actions. Nevertheless spy stories do discredit most of the facile defenses of covert operations that have become commonplace in electronic societies since the Second World War. More than a few spy stories are suspicious of ideal models of democracy. But even the tales that promote such models prefer to describe most governments as "bureaucratic" rather than "democratic."

At numerous points in The Spy Who Came In from the Cold, secrets are kept by various people from diverse others. The novel's world is full of secrecy, and so the world of secrecy turns out to be cold and dry and discouraging. Quite specific consequences seem to follow for the people who keep things secret, and others for the ones who do not. Yet there is an ironic twist or trick about the secrets kept. At the level of the laudable characters, keeping secrets cause events to go awry. The less trustworthy characters are so busy learning everybody else's secrets that we might describe them as managing or manipulating secrets more than keeping them. Their work, measured by their actual ends, goes much better. Presumably this testifies to the bureaucratic politics that inflate specific acts and tactics of secrecy into a larger strategy for secrecy that we could call "compartmentalization." Spies proceed only on a "need-to-know basis." You tell only people in your own part of the operation, and then only if they must know in order to operate well. That way, no spy caught can blow the covers of other spies in the secret service. By extension, spy agencies keep each piece of information restricted to one or two private, conspiratorial spaces. Think of them as closets, rather than forums. Because there is no "public space" where the knowledge becomes fully pooled or shared, however, the intelligent interpretation of information becomes difficult or impossible.

Systemically and personally, then, the compartmentalization and secrecy go awry. We readers do not know what is going on for much of le Carrés novels, though we get more clues overall than any actors save the few supposedly in Control. Liz does not know what is going on; but this is not surprising, since members of the public often become mere pawns for the players at the game of international intrigue. Nor, more tellingly, does Alec know. He often flatters himself that he does, but we learn that he has been cut out of the key loops. 
Until it is too late, he fails to understand the whole strategy pursued by Control. By the time he senses how Control is using him, he has little latitude left but to die. He thinks that he is engaged in one last act to get (revenge against) Mundt. Actually he is helping to solidify Mundt's position as a double agent. Alec does not know that Mundt is the mole burrowed high on the other side with the help of Control. Such a strategically placed double agent is far more valuable to Control than a lowly contact and runner like Leamas. By inference, we can look back on the first episode in the novel to suspect that Karl Riemeck probably was betrayed, not by his tie to a lady, but by his danger (or advantage) to Mundt. Anything that troubles Mundt imperils Control. Liz does not know, Fiedler does not know, Alec does not know about Mundt. Yet Control does. An ironical twist is that time and again the players in this game keep losing because there is a master manipulator behind the scenes. Secrecy has its intended effects only for Control - and by extension for Mundt too, though he remains Control's pawn.

Locally, at the level of the individual, secrecy insistently produces disasters in the world of spies. To be sure, publicity seems at least as liable to producing disasters in such a world, and spy stories develop that theme as well. In the le Carré classic, we may associate publicity with the heat of the spotlight that pins Alec to the wall where he dies, and secrecy with the cold that Alec suffers as a spy who must withhold himself from the caring of ordinary life. That is why Alec find his imprisonment (to make him look ready to defect) such an easy time. It differs little from the life he already has been living. Warmth, aside for heat and cold, would be the lot of everyday life and care.

Heat and cold also could evoke a contrast between idealism and realism in politics. This is standard imagery for the western hardball of Realpolitik. It pits warm and fuzzy idealists such as Liz or hot and passionate fanatics such as Fiedler against such cold-blooded and hard-nosed players as Control and Mundt. Within the world of international intrigue, Fiedler and Alec count for idealists; and notice how Alec warms to Fiedler as a fellow spy. Both, of course, get taken to the cleaners by Mundt and Control. Consistent with conventions of international intrigue, however, everyone in the novel is at least a would-be realist. Alec is a spy, with spies gener- 
ally supposed to be realists and hardball players. They are to break any eggs needed to make the patriotic omelet. Even though Liz is a warm, idealistic, touching person, one exceptionally large in spirit, her universalistic desire for justice contributes to a naïve Marxism that has her professing vague pieties in its hardball language. In the end, the book leaves us sad but thankful that neither Liz nor Alec has what it takes to keep playing hardball. Yet look at how the real hardballers fare.

Practitioners of international intrigue virtually require a labyrinthine, compartmentalized setting for politics. When deprived of it, they build it through their own deeds and weird surmises about the alleged plans of others. They love roundabout politics. They need circuitous appearances and subterfuges. They crave this as the clouding of human judgment that the cold-war character of "The Shadow" was able to achieve in order to render himself invisible to others. Here is the absurdly roundabout game of "Spy vs. Spy" ridiculed for decades by Mad Magazine. It is the world of James Bond gizmos, Rube Goldberg contraptions, Mission Impossible plots, and the relentless camouflage that leaves nearly nothing as it seems. It is a world that manufactures appearances so misleading that what is transparent or ordinary can be the best camouflage, and therefore the most suspicious, of all. It is a world where Descartes' "Evil Genius," who generates strange and misleading appearances for the rest of us to mistake as realities, would be right at home. It is one of the worst horrors of the late-modern political imagination made real. Then spy stories teach the awful truth that it is made real precisely in self-professed attempts to combat or even prevent itself.

Thus Alec Leamas recognized belatedly that he was starting to believe his own lies. By Control's early speech, if not before, we readers sense that something odd is happening; and we fear machinations far beyond Alec's control or awareness. We hope that they will be revealed as an action-adventure plot, where Alec turns out to have been a master planner or improviser. We hope that, somehow, off-stage, Alec has been orchestrating the eerie figures who watch him from a distance throughout the story. We hope that the end envisions him able to live happily ever after with Liz. But we "know" even so that we are in the clutches of a conventional spy tale done 
especially well, leaving happy endings less than likely and betrayals the order of the day.

So our hopes prove forlorn. Alec has been undiscerning. He has missed crucial clues, because he has been numbed by the long cold of spying. He is no longer suitably sensitive to his surroundings. He has ceased to stay alert in the coldly calculating manner required of successful combatants in this terrible war. He has been distracted by the warmth, the caring, the love forbidden to any proper spy or any other cold warrior worthy of the name. He has been swallowed whole by the maws of bureaucracy, to be chewed alive then spit out dead.

\section{... But Bureaucracy}

Longmead and Orrell, like most career politicians and administrators, enjoyed machinations, complexities, office politics. Such exercises had often seemed glutinous as mud to Aubrey, and with little reward to the spirit. Cleverness, mental agility, the arts of deception - for the purposes of probity, and good, of course - were truly pleasurable. His was not the deception of princes; rather, the jester's detached, vigorous, mocking intelligence. ${ }^{9}$

Craig Thomas

Spy stories are superb instructions in bureaucratic politics. Hannah Arendt argued in The Origins of Totalitarianism that bureaucrats and spies are essentially indistinguishable. She explained, moreover, how spying became a late-modern profession in connection with the same nineteenth-century imperialisms that developed the bureaucratic state. ${ }^{10}$ This enables us bureaucrats to glamorize our lives with small comparisons to James Bond. It connects the machinations of the spy to the political convolutions routine for businesses, churches, schools, or other organizations prone to the rationalization, red tape, image contests, turf wars, and information struggles of bureaucracies. It also links the humble micro-politics of bureaucracies experienced in our everyday lives to the arcane macro-politics of foreign affairs or international trade that can seem so distant from our personal concerns.

Bureaucrats are spies insofar as bureaucracies are arenas where information is power. To protect bureaucratic turf is, in part, to keep 
its defining information inaccessible to others - while augmenting that information and turf with activities from other agencies. The scholarly and political ideal defines bureaucracies as the most efficient modes of organization for large-scale activities in mass societies, regardless of substantive purpose. The reality, as everybody knows, is not so much efficient organization as a restoration of something like the chaos that Hobbes argued to afflict any state of nature. Bureaucracies tend both internally and externally to become wars of all against all. But now the object is scarce information, the key resource in late-modern life. This makes bureaucrats and their clients into something like secret agents, acting covertly to turn against others whatever information and turf they enjoy already, in other to secure more turf and information.

As Arendt argued, bureaucracy is the political arena of Kafka's K. Strangely, anonymously accused within a maize of agencies, $\mathrm{K}$ is turned around and upside-down in trying fruitlessly to get helpful information about his case. Eventually he is defeated utterly, becoming a lonely and confused fragment by story's end. Spy stories partake amply of this ethos, and they share Kafka's persistent concern with metamorphosis. In spy stories, this relates to alienating concerns of disguise and playing roles. Like Kafka's stories, moreover, tales of international intrigue often assume such transformations to be changes for the worse, not the better.

Spies are bureaucrats insofar as the craft of espionage operates within the bureaucratized setting of governments, business firms, and various other organizations late in modern societies. In playing these versions of king-of-the-mountain, we bureaucrats try to do unto others before they can do it unto us. We conceal our plans and penetrate the plans of others. We misinform and disinform the opposition, which often includes coworkers down the hall. And we do all this to give ourselves the best chance at bureaucratic success. When we read spy stories, we relive these personal episodes. We also acquire vicarious experience of bureaucratic situations we haven't faced yet but might at any time.

Bureaucratic intrigue and spying are species of hardball, realist politics. The standard criticism of having ends justify means is that the actual ends seldom accomplish the justification. What our ideals can seem to defend, our results cannot. Often what happens, as eve- 
rybody knows, is that the means supplant the intended ends. A familiar version of this disaster is the myth of Faust. We know it best these days through Mary Shelley's story of Frankenstein, arguably the founding novel of horror and science fiction as popular genres. ${ }^{11}$ Many spy stories also partake amply of the Faust myth. The spy sells his soul to the devil of an enemy, an ideal, a self-conception, even a romance. The devil - usually as secret information, powerful weaponry, or the dirty tricks of the spying trade that remain when its scruples go - is supposed to provide the spy with great powers to do good (and look good doing it). Without a soul, a code of proper conduct, however, the international actor loses track of the original ideals (such as legality or democracy) that might have justified the covert and dirty means that the spy actually pursues. The means become the ends: democracies turn into bureaucracies, laws into pretexts, pretenses into treacheries. By story's end, the question is whether the Faust figure will have gained the wisdom and humility to repent of his ruthless ways (redeeming the spy within his secondary world) or not (limiting the redemption to learning for us about the international relations of our primary world).

Again the conventional politics of spy stories seek to reconcile Machiavellian politics with the codes of honor that can keep them from self-betrayal and -destruction. The cold-war condition where anything goes is the hell to which Faustian spies are damned. International intrigue explores how to keep enough distance between the ends sought and the means used for calculations of means to ends to stay meaningful and legitimate. It tells how, when we fail to do this, when we bureaucrats or spies act without proper limits or restrictions, the ends collapse into the means. Then the spy story immerses us in the upshot: a mean existence where life is "solitary, poor, nasty, brutish, and short."

Late-modern spying is not simply penetrating enemy lines in order to know what is going on. That might be enough for military scouting in the nineteenth century, which entered the world of the western in the form of Kit Carson and other frontier scouts. From America's Civil War onward, though, even the scouting becomes highly technologized. Hot-air balloons fly over battle lines to photograph from above an enemy pattern of deployment. As late-modern espionage moves ever further into realms of techno- 
logical surveillance, the spy genre assimilates the scout ever more to the bureaucratic realms of high technology. The ties of spy to technology configure the settings of international intrigue in terms of the politics of technocracy: rule by technologies and their elites. $^{12}$

Technocracies develop the myth of "the technological imperative," the precept that can implies ought or must. If you can do it, you will do it. If you have the technical knowledge and resources to build that bomb, you must build it. If you have the means to build a new aircraft, you will assemble it. The spy genre put this into institutional forms that differ from everyday life, but the political dynamics are familiar readers from their daily experiences. The interdependent politics of bureaucracy and technology are no strangers to the inhabitants of advanced-industrial societies. Spy stories put these together to give readers a sense of technocracy at the levels of international relations and the national-security state.

By extension, the genre of international intrigue reaches beyond spy stories in any narrow sense. Tom Clancy's techno-thrillers of military and international relations are examples. They enjoy huge sales in America. They also exercise a great hold on Hollywood, where his intricate plots and technological extrapolations play to the penchant of films for lengthy thrillers with special effects. Clancy's novels are worth analyzing in the terms of this essay, but they are very long and less well-crafted than the efforts of Deighton, Thomas, and le Carré. ${ }^{13}$ Apparently, though, they are read just as avidly by professional spies, diplomats, and politicians - making their penchant for reliance on technological fixes all the more worrisome.

By the initial, cold-war logic of secret services, moreover, the rule is that they always already are doing it to us first. The spy genre acknowledges this mythos as (only a) part of our settings for international situations. Always it concedes there to be branches or divisions or officers of spy organizations committed to the proposition that the other side has escalated the technological confrontation to the next level that we can conceive. By analogy to the Peter Principle of bureaucratic promotion to the level of incompetence, a few spy stories show how we define "the next level" precisely by our current inability to conceive it in any specific terms. The challenge becomes to stop the principle of anticipation from turning into the principle 
of preemption and thence into the principle of escalation. Even Clancy shows interest in this perverse dynamic.

All the more, then, principles for international politics in the condition of cold war require that we get and keep (secret) information. So we act overtly and covertly to collect lots of data. Spy novels know that the main challenge is to configure the data, to see its patterns in order to interpret them. Otherwise we do not know what the data mean; we lack a determinate sense of their significance. Interpreting data is the classic and primary function assigned to "intelligence agencies." The covert activities of spies are mainly means to collect more grist for the intelligence mill. As spy stories tell, however, there are bureaucratic and reputational (as well as literary) reasons for the tail to wag the dog. So spy stories explore how the typical failures of intelligence are bureaucratic and interpretive, more than operational.

As operatives, spies work at the behest of officials bureaucratic and otherwise overtly political. Spies are the (secret) agents of the visible officials. "Agent" and "operative" are apt terms, implying that spies are mainly means: sheer tools or instruments of the state for international relations. Consequently officials tend to repress the humanity of their operatives. The genre suggests that spies get little respect as humans who are ends in themselves. Instead they are mere actors, performing scripts prepared by others. Their initiatives are supposed to be limited to the small adjustments necessary as any particular performance unfolds. Thus spies are instruments of someone else's "Control," the only name for the supervisor who runs Alec Leamas into the ground.

Le Carré tells us that "Control always came in on success." ${ }^{4}$ This says a lot about who and what Control is politically, at least as Alec Leamas suffers him. Underlings often regard their bosses this way in bureaucracies. Alec notices that Control is an expert bureaucratic operator who is seldom tarred with failure but always starred with success. Underlings can either envy or resent this. But Alec keeps his resentment all too much in check. He does the dirty work, whereas Control claims the credit. As underling, Alec's success is Control's, but Control is nowhere around when Alec gets into trouble.

Within bureaucracies, these devious devices are standard operating procedures. They are how people climb bureaucratic ladders. As 
overlings, moreover, Control and Mundt never seem to know anything self-incriminating about underling failures, leaving them to hold the bag on their own. Deniability of information is escape from responsibility. Overlings do not know what an underling is doing when he fails. Surely the underling was operating outside orders, at least outside their orders. Alec let Karl get friendly with a woman: that was his mistake, counter to Control's orders. To say that "Control always came in on success" is to evoke bureaucracy with precision.

One way to stay a step ahead in bureaucratic contests is, paradoxically, to resist regarding the process as a linear progression of one step after another. Spy stories practice us in conceiving the situation as a whole, a complex, a network of characters and events that reveals its structure at strategic points. If spies get the pattern well and tweak the pressure points, everything folds together into effective acts. Control does this brilliantly; Alec not nearly so well.

In this sense, we may say that Control genuinely controls, though this and many another spy novel stands by the generic lesson that even the best-laid plans "gang aft aglay." This authorial sense of control is one of the major attractions of the spy genre. An especially pure development of this aspect of the genre was the television series of Mission Impossible, in both its runs. In times of large institutions and repressions, the one experience denied most people most of the time is control. It is not surprising that we fantasize about it in popular forms such as international intrigue. The genre implies, as a corollary of the principle that "pride goeth before a fall," that a good sense of control is likely to signify its absence and a special susceptibility to manipulation. An enjoyable feature of many spy stories, nonetheless, is the idea that someone can be so clever in calculation and so skillful in performance that even an "agent" or "operative" could be "in control." For the business version of this bureaucratic fantasy, read The Firm, a legal thriller by John Grisham that takes Mission Impossible plotting to new heights. ${ }^{15}$

By this standard, the truly skillful agents are the ones who are able to control themselves. In the language of modern political theory, of course, this is to be sovereign. Or more simply, it is to become an independent agent - what we moderns call a self. Many spy tales have Mission Impossible plot structures of tightly scripted and tautly 
acted deeds meant to deceive and manipulate others into doing what the spy's side needs them to do but which they would not do without the spy's covert operation. (Here is the definition of power from Robert Dahl and many other Archimedeans that troubled political science in earlier times.) The television series of that name featured intricately, exquisitely timed operations with many gadgets, masks, and impersonations. Why doesn't a clockwork operation of this kind becoming boring? Because everything is cut so close and timed so finely that immense suspense builds about how the plans, equipment, or targets will prove themselves unpredictable - or the agents will prove themselves fallible. Can they keep functioning like machines long and well enough to make the risky business work? And if not, what then?

Most of the time, of course, there is some slight slip up near the end. Or at least, something appears to go wrong. At that point, the three standard plots for Mission Impossible diverge from their common stem. We might learn that something really did go wrong, but we learn that careful planning for contingencies enables the spy team to succeed anyway. This is control raised to a higher level of expertise. Or we might discover a bit later that the apparent bobble was actually a part of the plan, perhaps meant to distract or reassure the other side. This information is strategically withheld from us viewers, of course, and we thrill to the authors' and actors' deft manipulation of us through the story - as much or more as we thrill to the clever manipulation of the operatives' human targets. That raises the control to a still higher level, because then the agents are moving others through some sense of apparent failure by the agents, cunningly enabling the operatives to escape failure in the end. Or third, we find out that something really did go wrong but human courage, inventiveness, or luck can still carry the day. We are reassured that humans and their lives are not (mere) machines. When genuinely unforeseen problems arise, and a member of the Mission Impossible team spontaneously invents an ingenious and effective solution, the virtuosity of the response to changing conditions excites our highest approval.

The ability to adjust extemporaneously to shifting circumstances is what rhetoricians call invention. We might also call it innovation. And in jazz, the ability to adjust to rapid changes and turn them to advantage while coordinating responses with other players is called 
"improvisation." There it is celebrated as the highest mode of control. Improvisation is self-improvement perfected, made spontaneous and potentially endless. It exceeds or transcends other levels of control, because it leaves no controller on the scene. Great improvisers achieve what they do because they are at one with their colleagues and the situation. Little or no self-awareness remains. Improvisers immerse themselves in the music (or spying) at hand.

There are rules of thumb for improvisation, and it typically calls on a huge knowledge of music (or spying) generally and improvisational moves and modes particularly. During the time of improvisation, however, there is no time to stand mentally apart from the music (the covert operation). There is no time to criticize. There is no time for cognitive calculation of what notes to play next or how to play them. ${ }^{16}$ There is no time for planning what moves to make next or how to make them. As Zen has it, you are most yourself when you are not yourself, when there is no self there. Improvisers play "out of their minds" in the creative kind of insanity that Plato invoked in the Symposium. Thus do spies as secret agents transcend the limits of modern planning or calculation, of the modern self, even of the western civilization.

In political terms, improvisation is the Machiavellian ability to adjust to circumstances changed continually by the other actors in the situation - what Machiavelli termed Fortuna. Improvisation is the virtuos ability to take advantage of situations unforeseen and still changing before your very eyes. The genre of international intrigue agrees with most other popular genres that important dimensions of our politics at every level tend to transcend ordinary senses of control or even anticipation. These genres provide myriad experiences of vicarious action, enabling readers to refine their secondnature capacities of political judgment for comparable (but never identical) situations in their later lives. When you are improvising well, you are acting well. And then you are truly, in the fullest sense, in control of yourself and for yourself. Then you are not just being manipulated by others. Spy stories agree with most other genres on these political principles. More than that, they exercise us in the practice of such principles of political virtuosity.

That is the ambition of action stories generally: that the actor becomes so good at spontaneous and instantaneous responses to changing conditions that the actor survives and succeeds. As an impro- 
viser, the actor manages to do this in ways that we readers can anticipate in some respects (due to the conventionality of popular genres) but not others (due to the convention of improvisation). This ambition becomes prominent in recent spy stories, because they turn away from master controllers. They offer no sovereigns able to manipulate everything, because they agree with Hobbes that a lasting monopoly on power and resources is impossible in modern times. Increasingly, spy stories presume that there can be no puppet-master, pulling all the strings from behind the curtains or behind the scenes. In the international conditions beyond sovereignty, whether in cold-war situations where everybody has reason to distrust everybody else, or in code-of-honor settings where the plans of others are equally unpredictable but not so uniformly threatening, the challenge is to respond skillfully to new information.

Even bureaucracies have codes of honor; and the spies of Deighton, Thomas, and le Carré often honor those codes in clever ways that work to their professional and personal advantage. That is a big part of how they improvise. Even so, most spy stories reserve more room for codes of honor among spies than their supervisors. At times, therefore, the bureaucratic struggles are ruthless, cutthroat, with no holds barred, and no codes of honor observed. Control embodies this in The Spy Who Came In from the Cold. He talks as if spies on the same side enjoy a nearly professorial game of honor among professionals. But that is another feint and manipulation in a most ruthless game. Le Carré's stories insistently de-romanticize and un-chivalrize the Cold War in this way, not because he takes all thoughts of honor to be delusory and dangerous, but because he knows that they are desperately imperiled in our international politics. Perhaps the same may be said of bureaucracy as presented by the whole genre.

\section{And the Night-Manager State}

He would crop the secret octopus. He would give away its powers to separate, smaller agencies and make each of them separately accountable. He would deconstruct, decentralize, humanize. ${ }^{17}$

John le Carré 
When spy stories do get around to posing replacements for modern ideals of the sovereign state (and self), they tend to depart from the model states proposed by all the main ideologies of modern politics. They come to reluctant and partial accommodations with the latemodern cultures of bureaucracy and mass-mediated reputation. Yet they push beyond to something on the order of a postmodern politics. (This is what we should expect of a popular genre, since most are importantly postmodern innovations and include postmodern sensibilities from the very start.) The closest I can come at the moment to summarizing the spy genre's sense of an emerging state for postmodern conditions is to borrow the title image from le Carrés novel on The Night Manager.

The attunement of John le Carrés spy novels to problematics of late-modern political theory is manifest in many details. The Spy Who Came In from the Cold is, as I have tried to show, a brilliantly concise and deadly accurate tale of cold-war politics at the state and personal levels. Already it is renowned as a small classic of twentiethcentury literature, likely the greatest of spy stories, and the first in his succession of best-sellers. The Quest for Karla, three of the novels on the enigmatic George Smiley, would surely rate as the top series in the history of international intrigue. ${ }^{18}$ A preface to that quest (A Murder of Quality) and its postscript (The Secret Pilgrim) are fascinating in themselves and for their ties to the other Smiley novels. Literarily and politically, le Carré's only rival in the genre has been Graham Greene, who wrote earlier kinds of spy stories, less relevant to current conditions. ${ }^{19}$ Even so, my sense is that le Carré has outdone himself in The Night Manager. It is a long novel that hints in detail how we might theorize a distinctively postmodern state in international relations. In fact, one of its characters ruminates at various points about how to restructure the spy apparatus in particular, reigning it into a more democratic order. ${ }^{20}$

Le Carré moves from a strictly Hobbesian template for national and international affairs to problematics inspired by Lockean liberalism and Machiavellian republicanism. Other popular genres make similar moves, since the late-modern polities we most admire have become odd blends of democracy and bureaucracy with liberalism and republicanism. Westerns provide the most obvious examples, but many legal thrillers and science fictions come also to mind. In 
spy stories, conventionally and not just in the writings of le Carré, these confrontations often create nightmare conditions for a while, especially when the genre's preoccupations with less savory ideologies such as fascism and communism enter the picture. The usual suggestion of the genre is that the late-modern, bureaucratic politics of the national-security state imperil a genuinely postmodern politics of popular democracy or republican revivalism. As a result, many spy stories turn away from large institutions of politics to stress personal codes of personal honor. A recent le Carré novel includes this move along the way, but works overall to evoke a provocative model for postmodern states.

The model articulates features of the title character, The Night Manager. The title resonates to Hegel's famous phrase in describing the classically liberal notion of any modern, sovereign government as "the nightwatchman state." Hegel's argument is that, by contrast with the later liberal ideal of the welfare state, promoted by Hegel himself, the early liberal state is to be minimalist - virtually libertarian. The welfare state is to pursue the well-being of its citizens in every way possible, acting like a parent to the civil society it nurtures through programs administered by expert, rational, middle-class bureaucracies. It is activist, and it regards politics approvingly, as an appropriate part of the life of any individual or institutions. Humans achieve full development and maximum rationality through their participation in the welfare state, though it is to preserve ample spheres of private initiative and enjoyment in the form of a civil society of (increasingly) entrepreneurial individuals. ${ }^{21}$

Hegel maintained that the liberal state is a crude anticipation of the welfare state. This would leave the libertarian state as a strange ironization of it. Thus these images of minimal government appreciate only a part of the principles that Hegel and the twentieth century have presumed to make the welfare state into the acme of modern civilization. Ignoring or renouncing the ambitions of the welfare state, early liberal government is concerned mostly (and the libertarian state is occupied exclusively) with the bare essentials of national security and domestic tranquillity. Early in modern times, John Locke's Second Treatise of Government would provide the inspiriting sense of a minimal state for classical liberalism. ${ }^{22}$ Then the American Constitution as ratified with the Bill of Rights would offer a middle-modern 
template for the liberal state; while Robert Nozick's minimal government as proposed in Anarchy, State, and Utopia can exemplify the austere version of the nightwatchman state promoted by the libertarian politics of late-modern times. ${ }^{23}$ It reacts against the bureaucratized welfare states embraced by late-modern species of liberalism, socialism, and even (if more reluctantly) conservatism.

In principle, therefore, the nightwatchman state restrains itself from activities reaching beyond these rudiments of order. It strives only to enforce a minimal civilization necessary to take the brutal edge off the free-for-all competition among individuals and institutions in society. This is enough, classical liberals and libertarians argue, for private enterprise to become productive and pleasurable. Anything more, in fact, and the state not only violates (rather than enforces) human rights but also impedes productivity and the private enjoyment of goods. The sovereign and its associated politics are evils, because they coerce and constrain private individuals and institutions. Yet the classical liberal holds them to be necessary evils, because they provide the order and authority of civilization.

The image of the nightwatchman emphasizes that the sovereign is not supposed to finance or build or run any apparatus for producing the (private) goods that liberals suppose to make life collegial, rich, congenial, civil, and long. These production and payoff activities are daytime duties - conducted by the investors, developers, managers, and workers in the light of calculative reason. The nightwatchman works in darkness and shadow, by force and by fraud. But these evils are kept from infecting daylight production and consumption through strict limits on what superintendence is needed at night. The nightwatchman merely protects the plant while the owners and others sleep. Security and a few subsidiary services (such as stoking a furnace to keep temperatures suitable for the productive equipment in the off-hours) are the humble, dirty business of the nightwatchman. Thus he is a marginal employee of the main operation: low in responsibility, low in pay, lower in esteem. Yet the position is one of trust and therefore of honor, at least so it is supposed to be in relation to the daylight world of owning and doing.

Mainly, though, the nightwatchman keeps the building and its site under surveillance. As Michael Foucault emphasized, surveillance is the modern principle of politics presupposed by the Hobbe- 
sian sovereign and later highlighted by Jeremy Bentham's model for the modern prison, the Panopticon. ${ }^{24}$ To "discipline and punish" subjects, enforcing the compliance with civil law that takes the cold edge off competition, the activities of subjects must be visible to the sovereign. Thus the sovereign develops means to super-vise or overlook the citizenry. Then the national-security state takes technologies and practices of surveillance to new highs (or lows, depending on whether we regard it from the perspectives of the sovereign or its subjects). In this way, as spy stories stress, the libertarian minimizing of state powers gets swept aside in the interest of national security for times when the survival of the nation (or at least the state) seems imperiled from without and within. The surveillance state (as we may call it also) is big, muscular, active, and intrusive into the lives of its citizens - at least where its own security is at stake and, in the welfare-state versions, theirs as well. Thus do spy stories display the nightwatchman state turning into the nightmare state evoked by late-modern cacatopias of surveilliance such as We by Evgeny Zamiatin and dystopian devices of surveillance such as the two-way television in George Orwell's 1984. ${ }^{25}$ These developments receive ample attention in le Carrés novels, but the latest takes a more constructive turn.

As a stand-in for the postmodern state, le Carré's night manager is not a nightmare but a nightwatchman and much more. Thus the night manager is not only a model spy for our times but also an analogue of the model state. In a hotel, the night manager can be the second or third most responsible person. The overall manager is likely to be the (head) concierge. Little signals from le Carré suggest that we are to treat that "office" as our own, since he makes the head concierge at the main hotel served by Jonathan Pine into a rather ordinary fellow, something of a common man or average citizen. Serving the concierge most directly are the hotel's day and night managers. Which is the more important to the hotel's operations can vary from one hotel or time to the next. In general terms, though, the night manager has a strong claim on that position. The modern hotel is to serve its customers unobtrusively. This may require a bit of surveillance and a good more in the way of welfare services, but both should be kept off-stage as much as possible. Thus the night manager is not only responsible for welcoming late-comers into the 
hotel, but also for supervising quietly its major preparations and accommodations for all the guests. The night manager is usually the one who must respond to the odd requests at odd hours, handle the crises of the night, and the like. In addition, the night manager is the one who supervises the care of the physical plant (rather like the nightwatchman, but with much greater latitude and expectation). And finally, the night manager is the one who undertakes the genuinely distasteful and unpleasant business that is necessary at times for a hotel to do for its guests. These are key features of the postmodern state as night manager, and that last responsibility is where the spies and their covert action are placed: behind the scenes and working under cover of darkness but still within the larger picture.

Le Carrés further suggestions go beyond this model, so that we may say that the state is a night manager and more - just as Jonathan is a night manager and much more. In the epigraph to the section on sovereignty, le Carré himself suggests this move. The man with many voices is the night manager, Jonathan Pine. Each of the voices evoked in this passage, along with the many others that Pine sounds later in the novel, can be heard as an expression or style or aspect of the state as appreciated by recent tales of international intrigue. Likewise we might say that each of Pine's costumes, gestures, and roles could be a face or function of the best governments emerging in our times. (Not all the faces of a good government are good, handsome, or otherwise praiseworthy - except insofar as they contribute to an effective and worthwhile whole.) We may say that the officers discern, plan, decide, and on occasion command. The ranks listen, notice, act, and adapt any orders to their specific circumstances, then they report back to the officers. The cooks care for the basic sustenance of the rest, adding at the same time a little zest to their lives. By the same token, the deserters dissent, criticize, and eventually migrate elsewhere. And the "hidden reinforcements" of which Sophie speaks are not only sexual energies but Pine's efforts as a spy, an arms dealer, a surrogate father, a promising husband, a usurper of power, an enterprising soldier, a loyal son, and more.

Notice that the night-manager-and-more is still not sovereign in the modern, Hobbesian sense. Not even the concierge or the owner has that position. The hotel of postmodern culture is not so unified and Grand as the modern ideal wanted to make it, and the same 
goes for the state. ${ }^{26}$ Relatedly, the night-manager-and-more is not the center of the hotel. If there is one, it would lie with the guests. Not only are the guests a greatly mixed lot, going in all directions, but where would they be without the staff and the myriad support industries crucial for any great hotel? As the night manager is wellpositioned to appreciate, the postmodern hotel (culture) has no center, not in the western sense. As Yeats taught, that kind of center can no longer hold, culturally or politically or personally. To redress the anarchy that does or would otherwise result, depending on how we regard the new conditions for international relations, the need is for another mode of cohesion and coherence. As the night manager would know, spy stories suggest we locate this in the talk that permeates the hotel as a building, a (temporary) residence, an operation, a vocation, and even an ideal.

\section{International Relations as (Mythic) Talk}

We won. Not that the victory matters a damn. And perhaps we didn't win anyway. Perhaps they just lost. Or perhaps, without the bonds of ideological conflict to restrain us any more, our troubles are just beginning. Never mind. What matters is that a long war is over. What matters is the hope. ${ }^{27}$

John le Carré

Spy stories display international intrigue as talk, and they take talk to be not only tactical or strategic but also symbolic and mythic. Yet they emphasize that these capacities of talk are not always nice or neat. At times, they involve plenty of nastiness and ambiguity. And if talk means lying, though only in part, surely the spy story is the genre of popular culture most interested and intelligent about the politics of lying. As fiction, spy stories themselves are an exercise not only in talk but a kind of lying - the kind we should call mythmaking.

In the realm of spies, of course, there is lying and lots of it. Mainly there is the lying of leaving misleading impressions through leaving out something. "Lied by omission, as they all do, agents the world over. You teach them to cheat, to cover their tracks, and they cheat you as well." 28 Control's lament is the standing accusation against 
rhetoric implied by Aristotle when he defined it as enthymematic speech. The enthymeme is a matter of elliptical persuasion in public: it omits some of the potentially important premises or other steps in reasoning, maybe to save time or possibly to manipulate listeners. From Plato onward, myths have received the same criticisms as rhetoric. They are stories instead of arguments, but they leave out some prospectively important information while featuring other aspects of a situation, perhaps manipulatively.

Detective fiction addresses myth and rhetoric by investigating a claim or story and testing it against the clues, the evidence. Spy stories do some of this as well; but they do it more in the manner of westerns, where the cowboy tracks down the rustler who has absconded with a big part of the herd. Tracking figures importantly, if subtly, in even the earliest work by le Carré. All tracking depends on spies or other trackers reading the signs within their situations. What they can recognize as signs depends on a prior knowledge of how the situation should seem. For this to work in an international setting, the spy must know a lot, in order to work from a large base of informed expectations about a wide range of situations. The secret agent notices the clues, patterns them, and then interprets their significance. For the spy, many clues come in the form of talk; and much of the interpretative information concerns ordinary patterns of talk, which is to say, myths. Likewise the spy must know how to twist talk and myth to advantage, by lying to omit, misinform, or disinform. And the spy must know the myths to invoke persuasion, that the mis- and dis-information may appeal to the people to be misled. Of course, Control manages to do all these things with (and to) Alec.

Spy stories display bureaucracy and the national-security state as organized misrepresentation by lying and other means. As the Control complaint about lying agents may imply, the runners for agents have to expect to be treated as a part of the world of spy versus spy. It is not just spies for one side versus spies for the other side; it is each and every spy against each and every spy. The distrust, deception, and cheating happen in every direction, in almost every relationship.

Connotations of the world agent are telling in the bureaucratic connection of orders and obedience, deniability and blackmail. (All 
are modes of manipulative talk.) The agent is a mere means, a mere tool or instrument for accomplishing what western civilization regards as the will of another - say, Control. Agent is also our word for actor. We westerners say that we are "free agents." But then we drop the "free," and we (mis)understand that an agent pure and simple is someone permitted and able to act independently.

In the twilight zone between the modern poles of pure personal freedom and pure interpersonal determination stands what the study of international relations has been developing of late as accounts of "rational choice." In its terms, "agency theory" involves specifying how delegated authority and limits on choice can operate to extend one person's scope of action by extending a sphere of control over others who serve as its designated delegates. We westerners want to understand politics as re-presentational; and so we want to treat political actors as our agents, our operatives, our representatives. To represent can be to receive a considerable latitude about what to decide or do, though, and that is what is at issue in cold-war stories.

America had the OSS and then the CIA, the Soviet Union had the KGB, Britain has had its own Secret Service. Le Carré's insider talk of "the Circus" is a wonderful way to regard such spy institutions. These become "agencies" in a very peculiar sense that can escape the western politics of representation and the rational-choice accounts of agency. They become highly autonomous operators; worse, they end up becoming the tails that wag the dogs. They are supposed to be governmental means; they are supposed to be instruments of the people, to protect us from international intrigues. To impressive extents, however, they end up conducting their own foreign and military policies. As spy stories trace, they sometimes drive or even run the official foreign and military policies nominally administered by such institutions as the State Department or the Foreign Ministry. The Iran-Contra Affair, for example, displayed all these dimensions.

What spy stories try to do, therefore, is track the processes of international intrigue. The genre goes about this in ways meant to give us a sense of the bureaucratic and reputational politics of activities that might seem far away from ordinary people, but come home to them in important ways. The genre knows that international intrigue is a realm of lies, myths, rhetorical misrepresentations, and the like. Indeed it glories in the room for further myth-making that 
this creates. When the conditions are ripe, the genre's myths of international intrigue become insightful as criticisms and suggestions. Theorists and practitioners of international politics stand to learn more than a little from paying the popular genre of spy stories careful attention.

\section{Notes}

1 See John S. Nelson: "Stories of Science and Politics: Some Rhetorics of Political Research." In John S. Nelson, Allan Megill, and D. N. McCloskey, (eds.): The Rhetoric of the Human Sciences. Madison, University of Wisconsin Press, 1987, pp. 198-220.

2 Len Deighton: Spy Hook. New York, Ballantine Books, 1988, p. 223; italics added.

3 John le Carré: The Night Manager. New York, Ballantine Books, 1993, pp. 77-78.

4 Timothy Garton Ash: "The Real le Carré." New Yorker, 75, 3, March 15, 1999, pp. 36-45, on p. 45.

5 Stuart Woods: Deep Lie. Avon Books, New York, 1986, p. 59.

6 John le Carré: The Spy Who Came In from the Cold. New York, Bantam Books, 1963, p. 15.

7 See Guy Debord: Society of the Spectacle. Detroit, Red and Black, (1967), 1977; Jean Baudrillard: Simulations. Paul Foss, Paul Patton, and Philip Beitchman, trans., New York, Semiotext(e), 1983; and Murray Edelman: Constructing the Political Spectacle. Chicago, University of Chicago Press, 1988.

8 See Norberto Bobbio: The Future of Democracy. Richard Bellamy, ed., Roger Griffin, trans., Minneapolis, University of Minnesota Press, (1984), 1987. 9 Craig Thomas: A Hooded Crow. New York, HarperCollins, 1992, p. 259.

10 See Arendt: The Origins of Totalitarianism. New York, World, enlarged second edition, 1958, pp. 185-266.

11 See Mary Shelley: Frankenstein. New York, Bantam Books, 1818, (1981).

12 See Jacques Ellul: The Technological Society. John Wilkinson, trans., New York, Random House, 1964; Propaganda. Konrad Kellen and Jean Lerner, trans., New York, Knopf, 1971.

13 See Scott Shuger: "Paperback Fighter," Washington Monthly, 21, 10, November, 1989, pp. 10-18.

14 Le Carré: The Spy Who Came In from the Cold, p. 6. 
15 See John Grisham: The Firm. New York, Island Books, 1991.

16 See David Sudnow: The Ways of the Hand. London, Routledge and Kegan Paul, 1978.

17 Le Carré: The Night Manager, p. 62.

18 See John le Carré: Tinker, Tailor, Soldier, Spy. New York, Bantam Books, 1974; The Honourable Schoolboy. New York, Bantam Books, 1977; Smiley's People. New York, Bantam Books, 1980. More recently, le Carré continues in fine form in: Our Game. New York, Knopf, 1995; The Tailor of Panama. New York, Knopf, 1996; Single and Single. New York, Knopf, 1999.

19 See Cawelti and Rosenberg: The Spy Story, pp. 101-124, 156-186, and 231. Also see Graham Greene: This Gun for Hire. New York, Viking Press, 1936; The Confidential Agent. New York, Viking Press, 1939; The Power and the Glory. Viking Press, 1940; The Ministry of Fear. New York, Viking Press, 1943; The Heart of the Matter. Viking Press, 1948; The Quiet American. Viking Press, 1956; Our Man in Havana. New York, Viking Press, 1958; The Honorary Consul. New York, Viking Press, 1977; The Human Factor. New York, Viking Press, 1978.

20 The character is Rex Goodhew, a telling name in this connection. See le Carré: The Night Manager, pp. 6lff.

21 See G. W. F. Hegel: Philosophy of Right. T. M. Knox, trans., Oxford, Oxford University Press, (1821), 1952. Also see Shlomo Avineri: Hegel's Theory of the Modern State. Cambridge, Cambridge University Press, 1972.

22 See John Locke: Second Treatise of Government. C. B. Macpherson, ed., Indianapolis, Hackett, (1690), 1980.

23 See Robert Nozick: Anarchy, State, and Utopia. New York, Basic Books, 1974.

24 See Michel Foucault: Discipline and Punish. Alan Sheridan, trans., New York, Random House, (1977), 1979; Thomas L. Dumm: Democracy and Punishment. Madison, University of Wisconsin Press, 1987.

25 See Evgeny Zamiatin: We, Gregory Zilboorg. trans., New York, Dutton, 1924; George Orwell, Orwell's Nineteen Eighty-Four, Irving Howe, ed., New York, Harcourt Brace Jovanovich, (1963), second edition, 1982. 26 See Jim Collins: Uncommon Cultures. New York, Routledge, 1989.

27 John le Carré: The Secret Pilgrim. New York, Ballantine Books, 1990, p. 11.

28 Le Carré: The Spy Who Came In from the Cold, p. 6. 